\title{
Assessment of Social Vulnerability in the Evacuation Process from Mount Merapi: Focusing on People's Behavior and Mutual Assistance
}

\author{
Faizul Chasanah ${ }^{12^{*}}$ and Hiroyuki Sakakibara ${ }^{1}$
}

Received: 15/08/2020 / Accepted: 11/12/2020 / Published online: 08/03/2021

\begin{abstract}
In Merapi volcano mitigation, the cooperation within/between the local communities is a key strategy for effective evacuation. In the "sister village" scenario, the meeting area and shelter have been coordinated, but people's behavior has not been fully considered yet in the vulnerability assessment and government's contingency plan. The purpose of this study is to assess the people's behavior, mutual assistance, and social vulnerability index of pedestrian evacuation in four affected regencies. First, we measured the walking speed directly, conducted interviews with stakeholders, and focus group discussions with local communities. We used the multicriteria method and focused on two factors, social and age structure (young, vulnerable, and mutual assistance between them), and risk perception (work, rain, night, alert, and destination). The index reflects the distribution of actual walking speed, mutual assistance, and the government's plan. The result showed that mutual assistance groups have a higher walking speed than vulnerable people but lower than young people. Mutual assistance coordination is crucial to support vulnerable to effective travel time. The social and age structure of the social vulnerability index has a stronger risk influence than the perception factor in the evacuation process. However, these two factors have a minor impact on social vulnerability to the total population.
\end{abstract}

Key words: Pedestrians evacuation speed, people's behavior, mutual assistance, social vulnerability.

\footnotetext{
${ }^{1}$ Graduate School of Sciences and Technology for Innovation, Yamaguchi University

${ }^{2}$ Department of Civil Engineering, Faculty of Civil Engineering and Planning, Islamic University of Indonesia

* Corresponding author Email: b506wd@yamaguchi-u.ac.jp
} 


\section{INTRODUCTION}

Mount Merapi is the most active volcano in Indonesia, and the impact of the 2010 eruption was ranked third in the world (Guha-Sapir et al. 2016). During the last major eruption, more than 400,000 people evacuated, and over 50,000 people kept staying in the high-risk zona (Mei et al. 2013). In this disaster, crisis management problems such as congestion and evacuations delay were found. Congestion during evacuation not only reduces the effectiveness of evacuations but also leads to traffic accidents (Rizvi et al. 2007). Risk analysis is essential to develop efficient and adequate strategies for implementing the various components of development-oriented emergency aid and reconstruction planning to less vulnerable and more sustainable development measures (Federal Ministry for Economic Cooperation and Development 2004). Following UNESCO practice, Risk can be defined as = "Hazard x Vulnerability", with hazard referring to the physical events produced by an eruption and vulnerability including a consideration of the consequences for people, buildings, infrastructure, and economic activity (Scarpa and Tilling 1996).

There are four affected regencies in the Merapi eruption, and each Regional Disaster Management Agency has mitigation and prevention plans for handling this disaster. All maps about the hazard, vulnerability, and evacuation have become available and contingency plans documents have been updated by 2020. The regency governments are always improving development cooperation and the cooperation of the local community is a key strategy for effective evacuation. In the "sister village" scenario, the pair of meeting areas and shelter has been coordinated. The governments prioritize to evacuate vulnerable people from the meeting area to shelter, and young people need to evacuate from their houses to the meeting area or shelter by themselves (Boyolali District Disaster Management Agency 2019, Klaten District Disaster Management Agency 2018, Magelang District Disaster Management Agency 2017, Sleman District Disaster Management Agency 2019). Nakamura et al. (2017) confirmed that an effective relationship and communication with local communities is an essential factor in Community-based disaster-prevention meetings (CDPMs). It is crucial to improve not only understanding of disaster but also human communication and interaction between different generations. The risk perception is also one of the important factors in people's behavior during the evacuation process. The poor risk perception is characterized by an approximate personal representation of the volcanic processes, an excess of trust in concrete countermeasures, the presence of physical-visual obstructions, or cultural beliefs related to former eruptions (Lavigne et al. 2008). In this case, the community's behavior has not been fully considered yet by our government in vulnerability assessment. Therefore, the objective of this study is to observe the walking speed of the evacuation simulation, to analyze the people's behavior and mutual assistance, and to assess the social vulnerability index of social and age factor and risk perception factor. 


\section{DATA COLLECTION AND METHOD}

\subsection{Data collection}

This study focuses on hazard zone III of Mount Merapi. This means that the vulnerability and risk are extremely high and the priority to evacuate is highest. The area is located within a radius of $10 \mathrm{~km}$ from Mount Merapi. Administratively, this volcano is located on the border between Yogyakarta Special Province (Sleman Regency) and Central Java Province (Boyolali, Klaten, and Magelang Regencies). Data collection was done through a survey. The total of survey locations is 4 regencies involving 11 villages in Boyolali, 5 villages in Klaten, 19 villages in Magelang, and 7 villages (24 hamlets) in Sleman. These spots were determined according to the government contingency scenario and hazard map. Especially, the village area in Sleman is exceptionally large so the regency government maps the risks according to the hamlet. Table 1 is a description of the survey sites.

Table 1. Detail of survey sites

\begin{tabular}{ll}
\hline Regencies & \multicolumn{1}{c}{ Research Location } \\
\hline $\begin{array}{l}\text { Boyolali } \\
\text { (11 villages) }\end{array}$ & $\begin{array}{l}\text { Tlogolele, Klakah, Jrakah, Lencoh, Samiran, Surotoleng, Wonodoyo, } \\
\text { Jombong, Cluntang, Mriyan, and Sanggup }\end{array}$ \\
$\begin{array}{l}\text { Klaten } \\
\text { (5 villages) }\end{array}$ & Balerante, Tegalmulyo, Sidorejo, Panggang, and Bawukan \\
Magelang & Kaliurang, Nglumut, Ngablak, Ngargosoko, Tegalrandu, Mranggen, \\
(19 villages) & $\begin{array}{l}\text { Srumbung, Kemiren, Kapuhan, Wonolelo, Ketep, Ngargomulyo, Sewukan, } \\
\text { Sumber, Kalibening, Keningar, Sengi, Krinjing, and Paten }\end{array}$ \\
& $\begin{array}{l}\text { Ngandong, Nganggring, Tunggularum, Gondoarum, Sempu, Manggungsari, } \\
\text { Sleman } \\
\text { (24 hamlets) }\end{array}$ \\
& $\begin{array}{l}\text { Barat, Pelemsari, Pangukrejo, Jambu, Kopeng, Batur, Pagerjurang, Kepuh, } \\
\text { Manggong, Kalor, Kalkid, and Srunen }\end{array}$ \\
&
\end{tabular}

The purposive sampling method was used to collect the data. As secondary data, contingency plan documents from the Regional Disaster Management Agency in each regency and contingency plan documents from the village offices were checked. Primary data was obtained from the interviews with 50 stakeholders, forum group discussion with 658 local communities, and the walking speed of 518 volunteers was measured. The distribution of these respondents and volunteers already represented all affected villages. Interviews were conducted with the village leader and several stakeholders at the Regional Disaster Management Agency. The local communities participating in forum discussions and simulations consist of young and vulnerable people. Young people are defined as the group having ages 12 to 59 years old. While 
vulnerable people consist of breastfeeding mothers, pregnant women, children, elderly, and people with disabilities. People aged 0 to 11 years old are categorized as children, and aged more than 60 years old are categorized as elderly. The questionnaire instrument used was tested for validity and reliability using SPSS software. The test is done at a 5\% level of significance. The walking speed was measured directly where volunteers were asked to walk through a route for about $250 \mathrm{~m}$ to $500 \mathrm{~m}$ distance. The observer used a walking measure tool, timer, and handy cam to record the data. The actual evacuation distance from homes to the meeting areas of each affected village is different, but the average distance is about 1-3 km. It is obtained according to the evacuation map of each village by measuring the distance from the hamlets center to the meeting areas, and confirmed by the village leader. Figure 1illustrates how the survey was conducted.

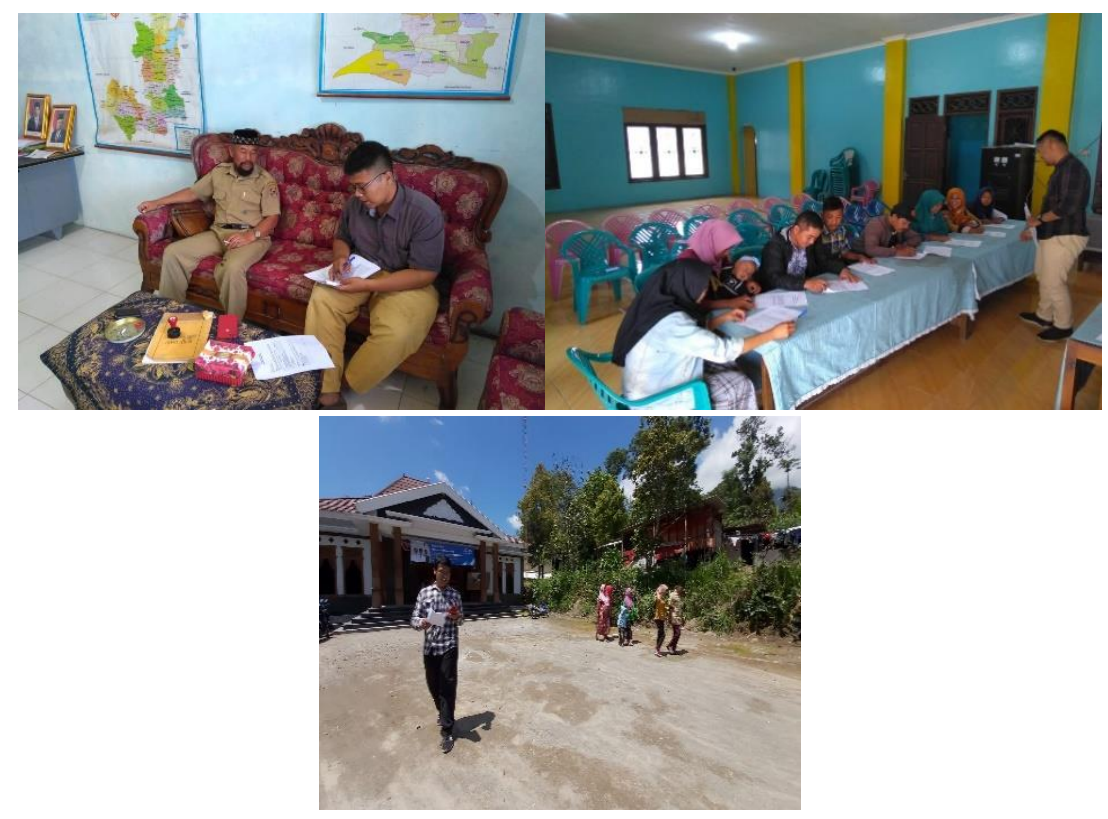

Figure 1. Documentation of interview, forum group discussion, and simulation

\subsection{Data analysis}

Walking speed data and mutual assistance impact are analyzed with descriptive statistics such as mean, standard deviation, and others. The Analysis of Variance (ANOVA) is also used to analyze this data. The Evacuation group and location were categorized into different groups according to their levels. The evacuation group was categorized as young without baggage, young with baggage, young and children, young and pregnant mother, young and elderly, young and disabled, breastfeeding mother and baby, pregnant mother, children, elderly, and disability. While the location was categorized as Boyolali, Klaten, Magelang, and Sleman regencies. All tests were done at a $5 \%$ level of significance. Furthermore, the social vulnerability index was assessed with a multicriteria method. 


\subsection{Social vulnerability index}

The risk analysis, risk evaluation, and risk management are part of the holistic concept of risk assessment (Glade and Bell 2004). There are two essential elements in risk assessment namely hazard and vulnerability. The probability of occurrence of a harmful natural event is defined as a hazard (Federal Ministry for Economic Cooperation and Development 2004). While the meaning of vulnerability is the characteristics of people, households, or economies that increase the likelihood to suffer damage given a hazard event. It is considered a formulation of many factors such as exposure, capacity, resilience, livelihood stress, susceptibility, sensitivity, and/or weakness (Lowe 2010). Velasquez (2003) confirmed that in case many vulnerability factors contribute to a hazard or a set of hazards, the total risk can be expressed as:

$$
R=\sum_{i=1, j=1, k=1}^{n} \underset{n}{n} w_{i} H_{i} *\left(\alpha_{i j k}\right) w_{j} V_{i j}
$$

Where $R$ represents the total risk, $H_{i}$ represents the different hazards, $V_{i j}$ represents the different vulnerabilities corresponding to these hazards, $\alpha_{i j k}$ is the social factor parameter that increases or decreases the hard vulnerability, $w_{j}$ is the weight of importance of a selected vulnerability factor, and $w_{i}$ is the weight of a hazard.

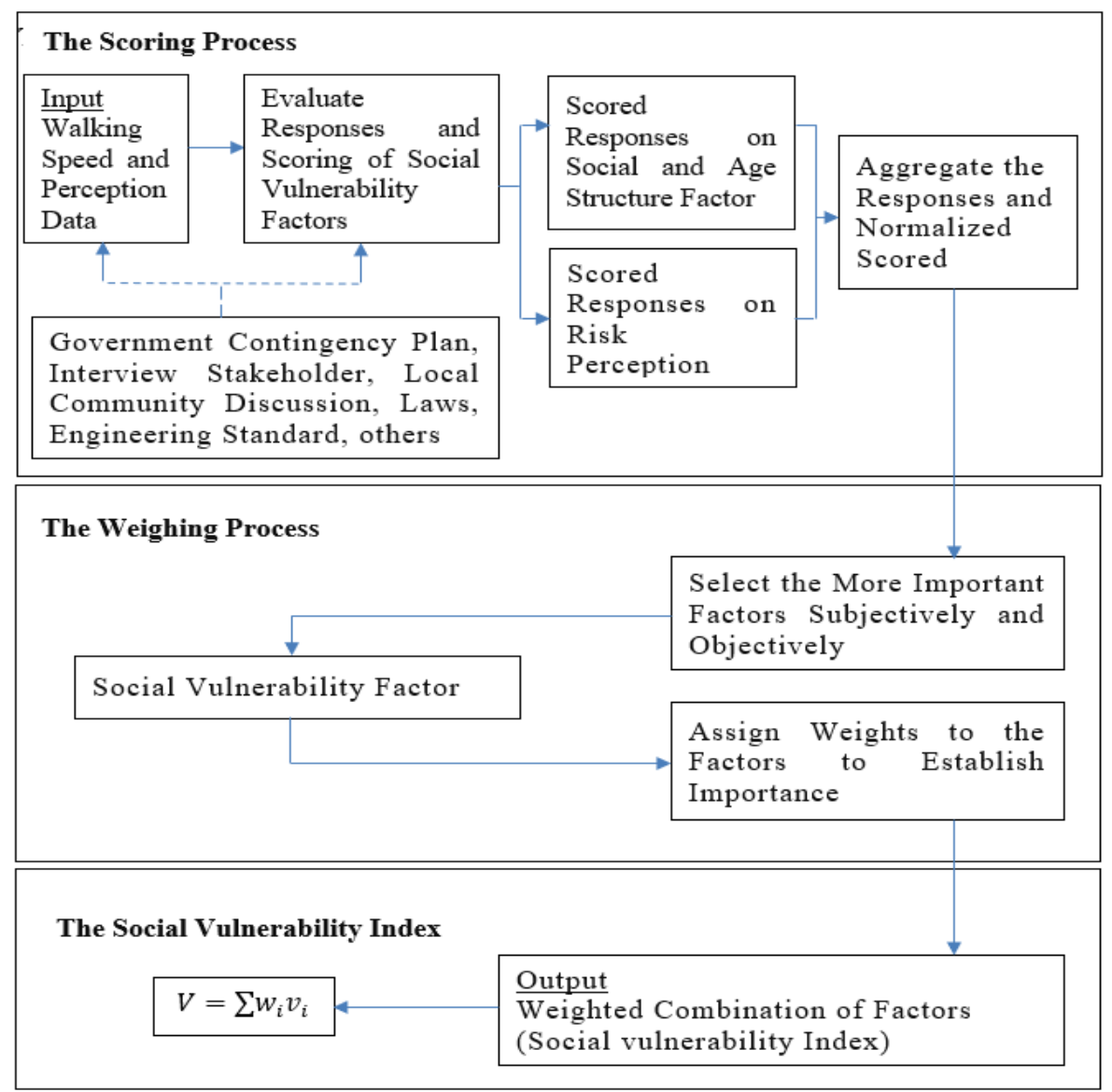

Figure 2. The assessment framework 
Federal Ministry for Economic Cooperation and Development (2004) explained that vulnerability factors have four classifications. They are economic vulnerability factors, physical vulnerability factors, social vulnerability factors, and environmental vulnerability factors. Especially, the variable of social vulnerability factor consists of the traditional knowledge system, risk perception, education, legal situation and human rights, civil participation, social organizations and institutions, legal framework, politics, social and age factor, health status, power structures and access to information. There are five top categories for the most useful social vulnerability. They are gender, public health condition, public infrastructure, and migration. Previous studies have been limited to measure the social vulnerability index in a natural disaster. Consequently, additional research is needed to develop the social vulnerability index and to develop appropriate variable weighting schemes and valid indices (Fatemi 2017). Therefore, an assessment of the social vulnerability index is purposed in this research. The community behavior analysis and mutual assistance strategy are our concern to get more effective pedestrian evacuation. In this case, people behavior variable is divided into two factors consisting of social and age structure and risk perception. Young people, vulnerable people, and mutual assistance groups are classification of social and age factors. While risk perception factor considers various conditions of working, rain, night, alert, and destination understanding. The assessment method is carried out in 3 stages including decision framework, criterion design, and multicriteria evaluation. The decision framework is shown in Figure 2.

Criterion design of the social and age structure factor is very dependent on walking speed data from the simulation. Truong et al. (2018) confirmed that the average speed and 15th percentile crossing speed from all survey sites and crossing types are $1.49 \mathrm{~m} / \mathrm{s}$ and $1.25 \mathrm{~m} / \mathrm{s}$, respectively. The overall 15 th percentile speed of $1.25 \mathrm{~m} / \mathrm{s}$ is close to the normal walking speed of $1.2 \mathrm{~m} / \mathrm{s}$ often adopted for both green walk and flashing red do not walk time design (Austroads 2016). According to Highway Capacity Manual (HCM) and Indian Roads Congress (IRC) method, pedestrian speed results in Level of Service (LOS) varies with gender, age group, group size, and trip purpose (Sangeeth and Lokre 2019). LOS of walkways and sidewalks is classified as high if the speed is above $1.3 \mathrm{~m} / \mathrm{s}$ (Transportation Research Board 2000). Each country has a different pedestrian mean speed. Pedestrian speed in developed countries is higher than in developing countries. Pedestrians of developing countries have a free flow mean walking speed of $1.2 \mathrm{~m} / \mathrm{s}$ (Rahman et al. 2012). Also, Yosritzal et al. (2018) confirmed that the average walking speed during the simulation of tsunami evacuation in Indonesia was $1.419 \mathrm{~m} / \mathrm{s}$. It is varied by age and gender of the evacuee. Based on the previous study, criterion design in the current study were determined by $1.40 \mathrm{~m} / \mathrm{s}$ standard because of the evacuation case approach and location of the same country. We consider the similarity of people's behavior in developing countries (Indonesia) and emergency response because studies about the pedestrian evacuation of volcanic eruptions are still limited. Meanwhile, the criterion design of risk perception factors depends on the questionnaire data from local communities. Table 2 and Table 3 clarify the scoring criteria for both factors. 
Table 2. Scoring criterion design of the social and age structure factor

\begin{tabular}{lccl}
\hline \multicolumn{1}{c}{ Categories } & Score & Description & \multicolumn{1}{c}{ Description to Consider (values) } \\
\hline $\begin{array}{l}\text { Young People } \\
\text { Vulnerable People }\end{array}$ & 0 & Not Vulnerable & $\begin{array}{l}\text { Faster than the mean walking speed } \\
\text { standard }(\geq 1.4 \mathrm{~m} / \mathrm{s})\end{array}$ \\
$\begin{array}{l}\text { Mutual Assistance } \\
\text { Group }\end{array}$ & 1 & Vulnerable & $\begin{array}{l}\text { Slower than the mean walking speed } \\
\text { standard }(<1.4 \mathrm{~m} / \mathrm{s})\end{array}$ \\
\hline
\end{tabular}

Table 3. Scoring criterion design of the risk perception factor

\begin{tabular}{ccl}
\hline Score & Description & \multicolumn{1}{c}{ Description to Consider (values) } \\
\hline $\begin{array}{c}\text { Work condition } \\
0\end{array}$ & $\begin{array}{c}\text { Not Vulnerable } \\
\text { Vulnerable }\end{array}$ & $\begin{array}{l}\text { Direct evacuation to the waiting area } \\
\text { Returned home to meet family }\end{array}$ \\
$\begin{array}{c}\text { Rain condition } \\
0\end{array}$ & $\begin{array}{c}\text { Not Vulnerable } \\
\text { Vulnerable }\end{array}$ & $\begin{array}{l}\text { Direct evacuation to the waiting area } \\
\text { Delay until the rain stop }\end{array}$ \\
$\begin{array}{c}\text { Night condition } \\
0\end{array}$ & Not Vulnerable & $\begin{array}{l}\text { Direct evacuation to the waiting area } \\
\text { Vulnerable }\end{array}$ \\
$\begin{array}{c}\text { Dlert condition } \\
0\end{array}$ & Not Vulnerable & Direct evacuation to the waiting area \\
1 & Vulnerable & Delay until seeing an eruption \\
Understanding of destination & Not Vulnerable & Understand the waiting area \\
0 & Vulnerable & Do not understand the waiting area \\
\hline
\end{tabular}

The next step is to assess the social vulnerability index using the multicriteria method. Based on the guidelines of quantifying the social aspects of disaster vulnerability, Velasquez (2003) explained about equation form as follow:

$$
V=\sum w_{i} v_{i}
$$

Where $V$ is vulnerability, $w_{i}$ is weight of factor $i, v_{i}$ is criterion score for vulnerability factor $i$.

The detailed assessment is described into four processes.

1. Determine the relative weight

Evaluate all respondent data and scoring based on the average delay evacuation categorized as vulnerable. The score of delayed evacuation is 1 and the score of direct evacuation is 0 . Where $R=$ raw score

2. Normalized the score 
Normalize the factors to $0-1$ ( 0 not vulnerable, $1=$ vulnerable).

Where $X i=($ Ri-Rmin $) /($ Rmax-Rmin $)$.

3. Calculate the criterion weights

Subjectively, the factor weights and normalized weight of important reveal are decided. Assigning criteria uses a simple pairing procedure utilizing at nine-step scale. This value indicates the relative scale of importance including $1 / 9,1 / 7,1 / 5,1 / 3,1,3,5,7$, and 9 . The meaning of $1 / 9$ is less important, 1 is standard, and 9 is more important.

4. Reveal the weighted linear combination of factors

Social vulnerability index $=w 1 v 1+w 2 v 2+\ldots .+w_{n} v_{n}$

\section{RESULT AND DISCUSSION}

\subsection{Characteristics of the local communities and population}

We collaborated with the affected village offices to invite the members of local communities to fulfill the population proportion and people's behavior. Volunteers from local communities are fully recommended by the village leader or hamlet leader. These volunteers represent 8 types of people's behavior including young people, children, pregnant mothers, breastfeeding mothers, elderly, disability, driver, and breeder. The children were represented by ages 5 to 11 years old, the young were represented by ages 12 to 59 years old, and the elderly were those aged 60 years old or more. While breastfeeding mothers are mothers carrying babies and toddlers. The volunteers who own private cars and trucks are categorized as drivers and having cattle and or goats are categorized as breeders. Each type of volunteers consisted of both female and male. We organized 16 volunteers in each village or hamlet to conduct focus group discussions and then measured the walking speed directly. However, at the execution time, some volunteers exceeded the number of the invitation, and some lacking. This condition was caused by situations such as rain, night, and limited disabled people.

The local communities in the four affected regencies have similar characteristics. The results of the primary and secondary data collection show that the population is dominated by young people with details for the Boyolali and Klaten Regency at 64\%, Magelang Regency at 81\%, and Sleman Regency at $72 \%$. The majority of the local community's livelihoods are agriculture and livestock farming. Data of students and workers outside the residence village for the affected regencies of Boyolali, Klaten, Magelang, and Sleman are about 5\%, 10\%, 20\%, and $25 \%$, respectively. It means that many residents stay in the villages during the daytime. This condition will influence the evacuation plan scenario if a disaster occurs at the time. As for single elderly data, the proportion of the population is exceedingly small, and elderly people usually live with their family or their homes nearby. Social culture with neighbors in these regencies is good and residents help each other. Therefore, the concept of "Mutual Assistance" between young people and vulnerable people in this evacuation case is possible to conduct.

The "sister village" scenario is a key strategy in mitigation development by the government. The cooperation concept is implemented through an agreement between the affected village 
and the sister village. The agreement includes the role of handling disaster emergencies such as providing shelter, logistics, and others. Sister village can be specified from the villages within the same regency or other regencies. On the other hand, evacuation transportation is the responsibility of the regency government and the affected communities. At level 3 status, the government will appeal to all residents for evacuation. Residents are expected to evacuate independently and simultaneously using their private vehicles from their homes to the meeting area and shelter in the sister village based on the evacuation map. The government will support staged evacuation from the meeting area to the shelter. In the first stage, the government will focus to evacuate vulnerable people and then young people without a private vehicle. Therefore, the effectiveness of pedestrian evacuation time from the house to the meeting area is crucial because of the uncertainty on the interval for changing from level 3 to 4 (eruption) status. A mutual assistance concept is being developed in this study to assess its effect. In the future, the government can also support this concept by conducting data collection and training for young and vulnerable people who have the status of family or neighbors. This strategy is essential for increasing public awareness, safety, and effective evacuation.

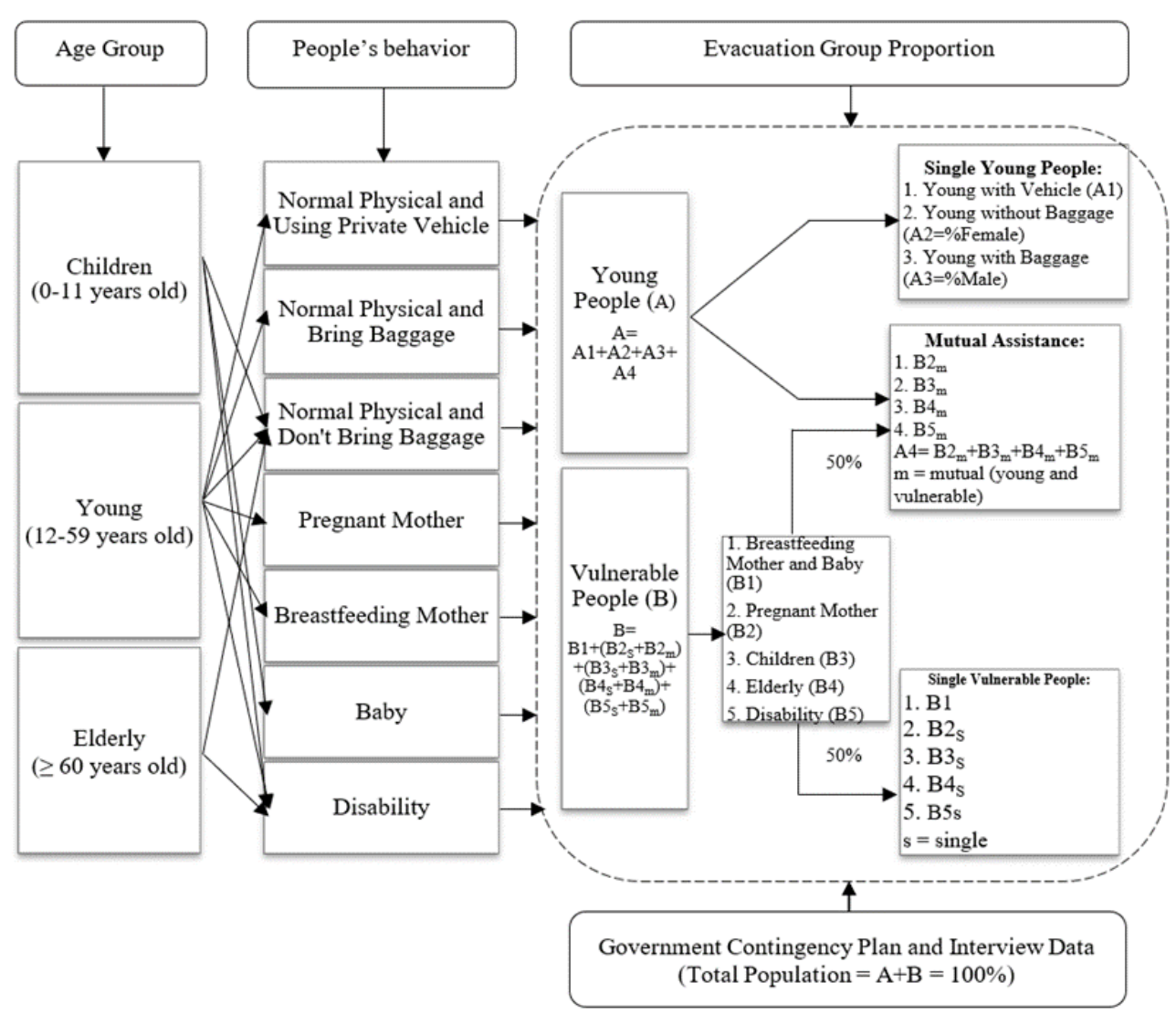

Figure 3. Conceptual of regency population

The population distribution of evacuation groups from home to the meeting area is divided into 3 groups namely young people, mutual assistance, and vulnerable people. Young people use a private vehicle and young people bring baggage are also included in the young group. 
The total number of people carrying baggage is represented by the percentage of young men population. Information about the population of young and vulnerable people and data of the local community's vehicle is obtained from the village contingencies plans and interviews with the village leader. We formulated the proportion of mutual assistance and single vulnerable people by $50 \%$ and $50 \%$. This assumption is determined according to the highest potential risk that will be handled by the government. Figure 2 is a detail of the regency population concept in the pedestrian evacuation process.

\subsection{Pedestrian evacuation speed}

The mean of young people's evacuation speed is $1.48(\mathrm{~m} / \mathrm{s})$ for Boyolali Regency, 1.7 (m/s) for Klaten Regency, 1.25 (m/s) for Magelang Regency, and $1.23(\mathrm{~m} / \mathrm{s})$ for Sleman Regency. Klaten Regency has the highest mean speed due to the downhill road conditions and good pavement. Whereas, Magelang and Sleman Regencies have a combination of surfaces between flat, uphill, and downhill which cause slower speeds. Boyolali Regency has a relatively flat and descending surface. These three regencies also have access roads from good to moderate damage. Overall, the result indicates that mutual assistance groups have a median speed between vulnerable and young people. For example, the mean speeds of young, mutual assistance (young and elderly), and elderly people in Boyolali are $1.48(\mathrm{~m} / \mathrm{s}), 1.22(\mathrm{~m} / \mathrm{s})$, and $0.99(\mathrm{~m} / \mathrm{s})$, respectively. This relationship is common in all regencies. The details of the mean walking speed and standard deviation in four affected regencies are shown in Table 4, Table 5, Table 6, and Table 7.

Table 4. Pedestrian evacuation speed in Boyolali Regency

\begin{tabular}{lcccc}
\hline \multicolumn{1}{c}{ Categories } & Number & Walking Speed (m/s) & \multicolumn{2}{c}{ Range } \\
& [Mean and Standard Deviation] & High & Low \\
\hline Young without Baggage & 18 & $1.48 \pm 0.43$ & 2.19 & 1.04 \\
Young with Baggage & 6 & $1.28 \pm 0.23$ & 1.51 & 0.97 \\
Young and Children & 5 & $1.45 \pm 0.37$ & 1.96 & 1.07 \\
Young and Pregnant Mother & 9 & $1.21 \pm 0.29$ & 1.67 & 0.83 \\
Young and Elderly & 9 & $1.22 \pm 0.35$ & 2.02 & 0.84 \\
Young and Disability & 3 & $0.86 \pm 0.17$ & 1.04 & 0.67 \\
Breastfeeding Mother and Baby & 8 & $1.23 \pm 0.30$ & 1.79 & 0.90 \\
Pregnant Mother & 8 & $1.25 \pm 0.38$ & 1.81 & 0.84 \\
Children & 4 & $1.22 \pm 0.42$ & 1.84 & 0.96 \\
Elderly & 5 & $0.99 \pm 0.11$ & 1.15 & 0.86 \\
Disability & 2 & $1.12 \pm 0.18$ & 1.25 & 1.00 \\
\hline
\end{tabular}


Table 5. Pedestrian evacuation speed in Klaten Regency

\begin{tabular}{llllc}
\hline \multicolumn{1}{c}{ Categories } & Number & \multicolumn{1}{c}{ Walking Speed $(\mathrm{m} / \mathrm{s})$} & \multicolumn{2}{c}{ Range } \\
& [Mean and Standard Deviation] & High & Low \\
\hline Young without Baggage & 9 & $1.70 \pm 0.62$ & 2.56 & 1.00 \\
Young with Baggage & 2 & $2.58 \pm 0.07$ & 2.63 & 2.53 \\
Young and Children & 3 & $1.46 \pm 0.72$ & 2.18 & 0.74 \\
Young and Pregnant Mother & 4 & $1.09 \pm 0.23$ & 1.32 & 0.77 \\
Young and Elderly & 4 & $1.45 \pm 0.48$ & 2.13 & 1.00 \\
Young and Disability & 2 & $1.44 \pm 0.15$ & 1.54 & 1.33 \\
Breastfeeding Mother and & & & & \\
Baby & 4 & $1.60 \pm 0.52$ & 2.10 & 0.99 \\
Pregnant Mother & 3 & $1.25 \pm 0.19$ & 1.39 & 1.04 \\
Children & 3 & $1.39 \pm 0.07$ & 1.47 & 1.34 \\
Elderly & 2 & $1.38 \pm 0.21$ & 1.52 & 1.23 \\
Disability & 1 & $0.46 \pm 0.00$ & 0.46 & 0.46 \\
\hline
\end{tabular}

Table 6. Pedestrian evacuation speed in Magelang regency

\begin{tabular}{lcccc}
\hline \multicolumn{1}{c}{ Categories } & Number & $\begin{array}{c}\text { Walking Speed (m/s) } \\
\text { [Mean and Standard Deviation] }\end{array}$ & \multicolumn{2}{c}{ Range } \\
High & Low \\
\hline Young without Baggage & 75 & $1.25 \pm 0.26$ & 1.85 & 0.79 \\
Young with Baggage & 2 & $0.80 \pm 0.42$ & 1.10 & 0.50 \\
Young and Children & 12 & $1.78 \pm 0.38$ & 2.33 & 1.25 \\
Young and Pregnant Mother & 9 & $1.02 \pm 0.43$ & 1.52 & 0.44 \\
Young and Elderly & 9 & $1.10 \pm 0.46$ & 1.39 & 0.40 \\
Young and Disability & 7 & $1.05 \pm 0.51$ & 1.79 & 0.55 \\
Breastfeeding Mother and Baby & 18 & $0.90 \pm 0.39$ & 1.45 & 0.55 \\
Pregnant Mother & 15 & $0.87 \pm 0.39$ & 1.45 & 0.40 \\
Children & 11 & $1.36 \pm 0.33$ & 1.83 & 1.05 \\
Elderly & 15 & $0.95 \pm 0.44$ & 1.94 & 0.39 \\
Disability & 11 & $0.88 \pm 0.45$ & 1.47 & 0.39 \\
\hline
\end{tabular}

In Table 5, it is found that young with baggage has a significantly higher speed than young people because the topographic contours tend to decrease, baggage capacity only contains important documents, and running action. Besides, the disabled person in Klaten Regency has 
the lowest speed $(0.46 \mathrm{~m} / \mathrm{s})$ due to leg defects and old age. There are many types of disability in this case including autism child, deaf, and limp legs with or without a wheelchair. When compared to disability speed in Boyolali Regency, it has a normal walking speed because of deaf, and mild leg defect condition. While Table 6 describes that the mutual assistance group between young and children has a dramatically higher speed than young people due to the children walked faster and the assistant followed them.

Table 7. Pedestrian evacuation speed in Sleman Regency

\begin{tabular}{lcccc}
\hline \multicolumn{1}{c}{ Categories } & Number & $\begin{array}{c}\text { Walking Speed (m/s) } \\
\text { [Mean and Standard Deviation] }\end{array}$ & \multicolumn{2}{c}{ Range } \\
High & Low \\
\hline Young without Baggage & 56 & $1.23 \pm 0.18$ & 1.64 & 0.99 \\
Young with Baggage & 14 & $0.95 \pm 0.16$ & 1.23 & 0.67 \\
Young and Children & 6 & $1.08 \pm 0.16$ & 1.25 & 0.81 \\
Young and Pregnant Mother & 11 & $1.02 \pm 0.15$ & 1.28 & 0.73 \\
Young and Elderly & 14 & $1.01 \pm 0.11$ & 1.15 & 0.80 \\
Young and Disability & 5 & $0.84 \pm 0.24$ & 1.26 & 0.69 \\
Breastfeeding Mother and Baby & 30 & $1.04 \pm 0.28$ & 1.56 & 0.37 \\
Pregnant Mother & 22 & $0.98 \pm 0.33$ & 1.43 & 0.32 \\
Children & 14 & $1.07 \pm 0.26$ & 1.57 & 0.63 \\
Elderly & 41 & $0.87 \pm 0.26$ & 1.38 & 0.55 \\
Disability & 7 & $1.11 \pm 0.30$ & 1.35 & 0.64 \\
\hline
\end{tabular}

In this paper, the One-Way ANOVA and Independent Samples T-Test are also used to analyze the speed data. Table 8 summarizes the result of the One-way ANOVA in SPSS Statistics. The test of normality and homogeneity of variances were fulfilled. At a $1 \%-5 \%$ level of significance, the result of the test implies that the mean walking speed in four regencies is not significantly different except in the category of young with baggage. It means the four affected regencies have similar community behavior in the pedestrian evacuation.

While in Table 9, the walking speed of young and vulnerable people are compared using the independent samples T-test. The vulnerable people group consists of breastfeeding mothers, pregnant mothers, elderly, and disabled people. Children are not included in each group because they sometimes walk faster than young people. The total of samples in this test was 158 for young people and 191 for vulnerable people. The result shows that $\mathrm{p}$-value $(\mathrm{sig})<0.05$. It indicates that the mean walking speed between these groups has a significant difference at a $5 \%$ level of significance. 
Table 8. Recapitulation of ANOVA result in each category (comparison between regencies)

\begin{tabular}{|c|c|c|c|c|c|c|}
\hline Categories & & Sum of Squares & $\mathrm{df}$ & Mean Square & $\mathrm{F}$ & Sig. \\
\hline Young People & $\begin{array}{l}\text { Between Groups } \\
\text { Within Groups } \\
\text { Total }\end{array}$ & $\begin{array}{l}.033 \\
.484 \\
.518\end{array}$ & $\begin{array}{c}1 \\
25 \\
26\end{array}$ & $\begin{array}{l}.033 \\
.019\end{array}$ & 1.715 & .202 \\
\hline Young with baggage & $\begin{array}{l}\text { Between Groups } \\
\text { Within Groups } \\
\text { Total }\end{array}$ & $\begin{array}{l}.554 \\
.204 \\
.759\end{array}$ & $\begin{array}{c}3 \\
20 \\
23\end{array}$ & $\begin{array}{l}.185 \\
.010\end{array}$ & 18.076 & .000 \\
\hline Young and Children & $\begin{array}{l}\text { Between Groups } \\
\text { Within Groups } \\
\text { Total }\end{array}$ & $\begin{array}{l}.318 \\
.542 \\
.860\end{array}$ & $\begin{array}{c}3 \\
22 \\
25\end{array}$ & $\begin{array}{l}.106 \\
.025\end{array}$ & 4.296 & .016 \\
\hline Young and Pregnant Mother & $\begin{array}{l}\text { Between Groups } \\
\text { Within Groups } \\
\text { Total }\end{array}$ & $\begin{array}{l}.056 \\
.640 \\
.697\end{array}$ & $\begin{array}{c}3 \\
29 \\
32\end{array}$ & $\begin{array}{l}.019 \\
.022\end{array}$ & .851 & .477 \\
\hline Young and Elderly & $\begin{array}{l}\text { Between Groups } \\
\text { Within Groups } \\
\text { Total }\end{array}$ & $\begin{array}{l}.140 \\
1.161 \\
1.301\end{array}$ & $\begin{array}{c}3 \\
31 \\
34\end{array}$ & $\begin{array}{l}.047 \\
.037\end{array}$ & 1.246 & .310 \\
\hline Young and Disability & $\begin{array}{l}\text { Between Groups } \\
\text { Within Groups } \\
\text { Total }\end{array}$ & $\begin{array}{l}.121 \\
.444 \\
.565\end{array}$ & $\begin{array}{c}3 \\
13 \\
16\end{array}$ & $\begin{array}{l}.040 \\
.034\end{array}$ & 1.184 & .354 \\
\hline Breastfeeding Mother & $\begin{array}{l}\text { Between Groups } \\
\text { Within Groups } \\
\text { Total }\end{array}$ & $\begin{array}{l}.254 \\
1.418 \\
1.672\end{array}$ & $\begin{array}{c}3 \\
56 \\
59\end{array}$ & $\begin{array}{l}.085 \\
.025\end{array}$ & 3.338 & .026 \\
\hline Pregnant Mother & $\begin{array}{l}\text { Between Groups } \\
\text { Within Groups } \\
\text { Total }\end{array}$ & $\begin{array}{c}.955 \\
5.544 \\
6.499\end{array}$ & $\begin{array}{c}3 \\
44 \\
47\end{array}$ & $\begin{array}{l}.318 \\
.126\end{array}$ & 2.526 & .070 \\
\hline Children & $\begin{array}{l}\text { Between Groups } \\
\text { Within Groups } \\
\text { Total }\end{array}$ & $\begin{array}{c}.614 \\
2.533 \\
3.148\end{array}$ & $\begin{array}{c}3 \\
28 \\
31\end{array}$ & $\begin{array}{l}.205 \\
.090\end{array}$ & 2.263 & .103 \\
\hline Elderly & $\begin{array}{l}\text { Between Groups } \\
\text { Within Groups } \\
\text { Total }\end{array}$ & $\begin{array}{l}.133 \\
1.645 \\
1.778\end{array}$ & $\begin{array}{c}3 \\
59 \\
62\end{array}$ & $\begin{array}{l}.044 \\
.028\end{array}$ & 1.591 & .201 \\
\hline Disability & $\begin{array}{l}\text { Between Groups } \\
\text { Within Groups } \\
\text { Total }\end{array}$ & $\begin{array}{c}.485 \\
2.618 \\
3.103\end{array}$ & $\begin{array}{c}3 \\
17 \\
20\end{array}$ & $\begin{array}{l}.162 \\
.154\end{array}$ & 1.050 & .396 \\
\hline
\end{tabular}

\subsection{Mutual assistance impact}

Figure 3 shows the effects of mutual assistance on walking speed. Mutual assistance means that young people evacuate with vulnerable people. For young people, evacuation with vulnerable people generally means the decline of walking speed. However, the mutual assistance between young and children in Magelang Regency reaches the top speed at $1.78 \mathrm{~m} / \mathrm{s}$. This result may occur due to a lack of coordination between them. Effective evacuation time is an important goal but avoiding high risk is also essential. Therefore, mutual assistance coordination is crucial for vulnerable people's safety. Figure 3 explains that the mean speed of young people decreases sharply in four affected regencies. The biggest drop is in the young and disability group at intervals of $0.20 \mathrm{~m} / \mathrm{s}-0.62 \mathrm{~m} / \mathrm{s}$. On the other hand, the group speed of young and children, young and pregnant mothers, and young and elderly have a slight deflation. 
Table 9. The speed comparison of young and vulnerable people according to the independent samples T-test

\begin{tabular}{|c|c|c|c|c|c|c|c|c|c|c|}
\hline & & \multicolumn{4}{|c|}{$\begin{array}{l}\text { Levene's Test } \\
\text { for Equality of } \\
\text { Variances }\end{array}$} & \multicolumn{5}{|c|}{ t-test for Equality of Means } \\
\hline & & \multirow[b]{2}{*}{$\mathrm{F}$} & \multirow[b]{2}{*}{ Sig. } & \multirow[b]{2}{*}{$\mathrm{t}$} & \multirow[b]{2}{*}{ df } & \multirow{2}{*}{$\begin{array}{c}\text { Sig. } \\
\text { (2-tailed) }\end{array}$} & \multirow{2}{*}{$\begin{array}{c}\text { Mean } \\
\text { Difference }\end{array}$} & \multirow{2}{*}{$\begin{array}{l}\text { Std. Error } \\
\text { Difference }\end{array}$} & \multicolumn{2}{|c|}{$\begin{array}{l}\text { 95\% Confidence } \\
\text { Interval of the } \\
\text { Difference }\end{array}$} \\
\hline & & & & & & & & & Lower & Upper \\
\hline \multirow[t]{2}{*}{$\begin{array}{l}\text { Speed } \\
(\mathrm{m} / \mathrm{s})\end{array}$} & $\begin{array}{l}\text { Equal } \\
\text { variances } \\
\text { assumed }\end{array}$ & 3.205 & .074 & 8.277 & 347 & .000 & .30197 & .03648 & .23022 & .37373 \\
\hline & $\begin{array}{l}\text { Equal } \\
\text { variances not } \\
\text { assumed }\end{array}$ & & & 8.375 & 345.512 & .000 & .30197 & .03606 & .23105 & .37289 \\
\hline
\end{tabular}

In Figure 4, there is a clear difference in the walking speed between vulnerable dan mutual assistance in four affected regencies. Children, elderly, and disabled people have a significant impact on this mutual assistance action. In the case of disability, the mean walking speed is increased from $0.89 \mathrm{~m} / \mathrm{s}$ to $1.05 \mathrm{~m} / \mathrm{s}$. The SPSS software is also used to confirm a speed comparison of mutual assistance and vulnerable people. Test of normality and homogeneity of variances were fulfilled. The paired samples T-test result shows that $\mathrm{p}$-value $(\mathrm{sig})<0.05$. It describes that pedestrian evacuation speed of mutual assistance and vulnerable have a significant difference at a $5 \%$ level of significance (Table 10). Especially, this vulnerable group is the elderly and disabled people.

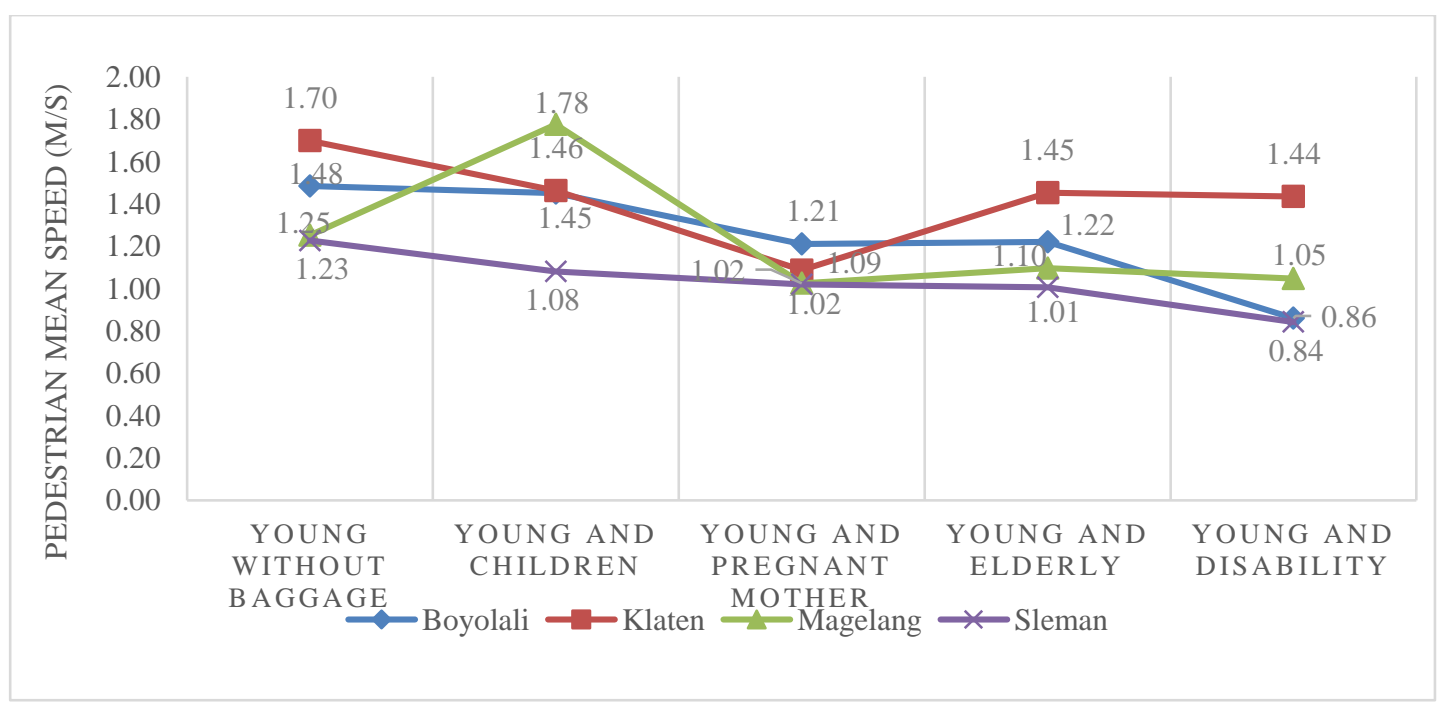

Figure 4. The mean walking speed comparison between young people and mutual assistance 


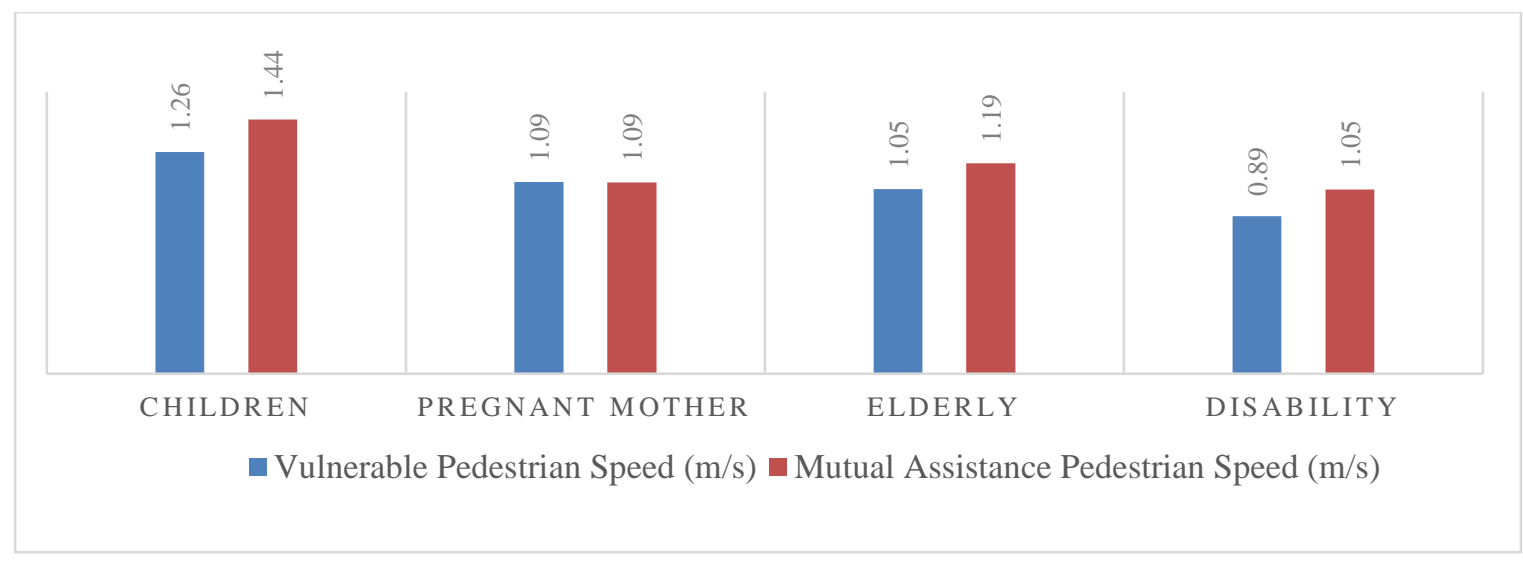

Figure 5. The mean walking speed comparison between vulnerable people and mutual assistance

Table 10. The speed comparison of mutual assistance and vulnerable people according to the paired samples T-test

\begin{tabular}{|c|c|c|c|c|c|c|c|c|c|c|}
\hline & & $\begin{array}{l}\text { Lever } \\
\text { for } \mathrm{E} \\
\text { of } \mathrm{Va}\end{array}$ & $\begin{array}{l}\text { s Test } \\
\text { dality } \\
\text { ances }\end{array}$ & & & t-test fo & r Equality of & Means & & \\
\hline & & & & & & & & & $\begin{array}{r}95 \% \text { Co } \\
\text { Interva } \\
\text { Diffe }\end{array}$ & $\begin{array}{l}\text { fidence } \\
\text { of the } \\
\text { ence }\end{array}$ \\
\hline & & $\mathrm{F}$ & Sig. & $\mathrm{t}$ & df & (2-tailed) & Difference & Difference & Lower & Upper \\
\hline & $\begin{array}{l}\text { Equal } \\
\text { variances } \\
\text { assumed }\end{array}$ & .088 & .768 & 2.637 & 135 & .009 & .15968 & .06056 & .03990. & 27946 \\
\hline$(\mathrm{m} / \mathrm{s})$ & $\begin{array}{l}\text { Equal } \\
\text { variances not } \\
\text { assumed }\end{array}$ & & & 2.587 & 103.801 & .011 & .15968 & .06173 & .03727. & 28209 \\
\hline
\end{tabular}

\subsection{Social vulnerability index}

The social vulnerability index is assessed from two points of view, subjectively and objectively. Then both are compared by focusing on two people's behavior factors namely social and age structure, and risk perception. We use the normalized weight of importance reveal based on a group evaluation by stakeholders and the local community to get subjective results. All affected regencies have the same weight of vulnerability. Regional characteristics involving topography, livelihoods, and community culture are similar so the calculation of criteria score each regency can be represented by a common score. Consequently, the social vulnerability index in four affected regencies is subjectively the same. In contrast to objectively, we use the weight of importance based on the total population so a different index in each regency is obtained. Detailed results of common score, vulnerability weight, social vulnerability index is referred from Table 11 to Table 14. 
Table 11. A common score of the social and age structure (all affected regencies)

\begin{tabular}{|c|c|c|c|c|}
\hline \multirow{2}{*}{ Categories } & \multirow{2}{*}{ Number } & \multicolumn{2}{|c|}{ Pedestrian Speed (m/s) } & \multirow{2}{*}{$\begin{array}{c}\text { Common } \\
\text { Score } \\
\text { (Normalized) }\end{array}$} \\
\hline & & Mean & Standard Deviation & \\
\hline Young without Baggage & 158 & 1.42 & 0.37 & 0.484 \\
\hline Young with Baggage & 24 & 1.40 & 0.22 & 0.496 \\
\hline Young and Children & 26 & 1.44 & 0.41 & 0.460 \\
\hline Young and Pregnant Mother & 33 & 1.09 & 0.27 & 0.875 \\
\hline Young and Elderly & 36 & 1.19 & 0.35 & 0.722 \\
\hline Young and Disability & 17 & 1.05 & 0.27 & 0.908 \\
\hline Breastfeeding Mother and Baby & 60 & 1.19 & 0.37 & 0.709 \\
\hline Pregnant Mother & 48 & 1.09 & 0.32 & 0.834 \\
\hline Children & 32 & 1.26 & 0.27 & 0.699 \\
\hline Elderly & 63 & 1.05 & 0.25 & 0.919 \\
\hline Disability & 21 & 0.89 & 0.23 & 0.985 \\
\hline
\end{tabular}

Table 12. A common score of the risk perception (all affected regencies)

\begin{tabular}{lccccc}
\hline \multicolumn{1}{c}{ Categories } & \multicolumn{4}{c}{ Criterion Score } & \multicolumn{2}{c}{ Common } \\
& Boyolali & Klaten & Magelang & Sleman & Score \\
\hline Work Condition & 0.900 & 0.733 & 0.815 & 0.727 & 0.794 \\
Rain Condition & 0.080 & 0.117 & 0.103 & 0.061 & 0.090 \\
Night Condition & 0.040 & 0.017 & 0.011 & 0.029 & 0.024 \\
Alert Condition & 0.040 & 0.017 & 0.011 & 0.025 & 0.023 \\
Understanding of Destination & 0.600 & 0.317 & 0.130 & 0.108 & 0.289 \\
\hline
\end{tabular}

Based on Table 14, the subjective and objective assessment shows that the social and age structure factor has a higher index than the risk perception factor. It means that the social and age structure factor has strong risk influence in the pedestrian evacuation process. Overall, the subjective social vulnerability index is higher than the objective index. This phenomenon occurs because the subjective view focuses on the evacuation problem of vulnerable people and the objective view depends on the group population in the communities. The objective index in the four regencies is low due to the elderly people proportion is not large. Magelang Regency represents the highest objective index for the social and age structure factor, and Sleman Regency reflects the highest objective index for the risk perception factor. Nevertheless, both factors have a low objective index. It indicates a minor impact on social vulnerability to the total population. 
Table 13. Weight of vulnerability in the subjective and objective view

\begin{tabular}{clccccc}
\hline & & Weight of & \multicolumn{3}{c}{ Regency Weight (Objective) } \\
No & \multicolumn{1}{c}{ Categories } & $\begin{array}{c}\text { Vulnerabilit } \\
\text { y }\end{array}$ & $\begin{array}{c}\text { Boyolal } \\
\text { i }\end{array}$ & $\begin{array}{c}\text { Klate } \\
\text { (Subjective) }\end{array}$ & $\begin{array}{c}\text { Magelan } \\
\text { g }\end{array}$ & Sleman \\
& & & & & & \\
\hline Social and Age Structure Factor & 0.000 & 0.488 & 0.432 & 0.130 & 0.439 \\
\hline 1 & Young with Vehicle & 0.010 & 0.003 & 0.032 & 0.306 & 0.083 \\
2 & Young without Baggage & 0.029 & 0.003 & 0.032 & 0.301 & 0.082 \\
3 & Young with Baggage & 0.087 & 0.200 & 0.200 & 0.025 & 0.144 \\
4 & Young and Children & 0.029 & 0.010 & 0.010 & 0.007 & 0.002 \\
5 & Young and Pregnant Mother & 0.087 & 0.070 & 0.070 & 0.104 & 0.083 \\
6 & Young and Elderly & 0.087 & 0.010 & 0.010 & 0.010 & 0.008 \\
7 & Young and Disability & & & & & \\
& Breastfeeding Mother and & 0.087 & 0.070 & 0.070 & 0.043 & 0.040 \\
8 & Baby & 0.146 & 0.005 & 0.005 & 0.004 & 0.002 \\
9 & Pregnant Mother & 0.087 & 0.100 & 0.100 & 0.013 & 0.072 \\
10 & Children & 0.146 & 0.035 & 0.035 & 0.052 & 0.042 \\
11 & Elderly & 0.204 & 0.005 & 0.005 & 0.005 & 0.004 \\
12 & Disability & & & & & \\
\hline Risk Perception Factor & Work Condition & 0.310 & 0.012 & 0.026 & 0.048 & 0.048 \\
\hline 1 & Rain Condition & 0.034 & 0.247 & 0.244 & 0.238 & 0.238 \\
3 & Night Condition & 0.034 & 0.247 & 0.244 & 0.238 & 0.238 \\
4 & Alert Condition & 0.517 & 0.247 & 0.244 & 0.238 & 0.238 \\
5 & Understanding of Destination & 0.103 & 0.247 & 0.244 & 0.238 & 0.238 \\
\hline
\end{tabular}

Table 14. Social vulnerability index comparison

\begin{tabular}{lcccc}
\hline \multirow{2}{*}{ Regencies } & \multicolumn{2}{c}{$\begin{array}{c}\text { Index of Age Structure Factor } \\
\text { Subjective }\end{array}$} & Objective & Index of Risk Perception Factor \\
& 0.806 & 0.324 & 0.292 & 0.115 \\
Boyolali & 0.806 & 0.352 & 0.292 & 0.124 \\
Klaten & 0.806 & 0.494 & 0.292 & 0.139 \\
Magelang & 0.806 & 0.338 & 0.292 & 0.147 \\
Sleman & & & \\
\hline
\end{tabular}

\subsection{Comparison with previous studies}

Yosritzal et al. (2018) observed the walking evacuation speed of tsunami disaster in Padang, West Sumatera, Indonesia. They involved 9 volunteers, 6 observers, 1 route with 5 segments in their simulation. In conclusion, the mean walking speed during the evacuation was 1.419 $\mathrm{m} / \mathrm{s}$. The group of age 20-40 years was found to walk $11 \%$ faster than children and $7 \%$ faster 
than elderly people. Male was discovered $10 \%$ faster than female in the same group. Jumadi et al. (2019) compared the evacuation scenario with an agent-based model between simultaneous and staged of Merapi Volcano in Sleman Regency, Yogyakarta, Indonesia. The results confirm that the staged scenario has a better ability to reduce the potential traffic congestion during the peak time. The time interval between the stage was divided into 5 districts namely Cangkringan, Ngemplak, Pakem, Tempel, and Turi. The average travel time to reach a major road was 23.8 minutes. However, the simultaneous strategy has better performance regarding the speed of reducing the risk. The study of Jumadi et al. (2019) has several limitations such as the variability of population behavior that has not been involved in this initial simulation development, and the government contingency plans have not yet been considered. Meanwhile, Nugraha et al. (2019) confirmed the risk assessment of Mount Merapi in the settlement area of Sleman Regency and concern on the mapping of eruption risk. The result shows that there is still a large risk in the Regency. Therefore, an appropriate strategy in mitigation planning is needed.

Klein et al. (2019) presented the four challenging principles for integrated community-based and ecosystem-based disaster risk reduction in mountain systems. They are governance and institutional arrangement that appropriate local needs, empowerment, and capacity-building to strengthen community resilience, discovery and sharing of constructive practices that combine local and scientific knowledge, and oncoming focused on well-being and equity. Besides, the presence of too many cooperators or defectors in the evacuation group is not conducive to safe evacuation. It is found that heterogeneous pedestrian speeds can increase the evacuation efficiency to a certain extent. The total evacuation time can be reduced if $20 \%$ of the pedestrians slow down. The evacuation time is the shortest when the radius is about 4 cells (Zou et al. 2020). In this present research, we focused on the local community behavior in four affected regencies especially the "mutual assistance" study. The index output reflects the distribution of actual walking speed, mutual assistance, and the government's plan updating in 2019 . Therefore, this study is a development from previous research to get a more effective and practical evacuation plan for the considered by the government.

\section{CONCLUSIONS}

This paper presents the influence of local community behavior and mutual assistance in the pedestrian evacuation process. Actual walking speed and risk perception are the main variables. The results showed that mutual assistance can be effective to reduce any risk during evacuation. Probably, the reduced evacuation time is not so big but vulnerable people may be left if young people do not care about them. The social and age structure of the social vulnerability index has a stronger risk effect than the perception factor. However, these two factors have a minor impact on social vulnerability to the total population. In future work, it is necessary to develop an evacuation model of the breeder and cattle because they must be evacuated simultaneously at level 3 status according to the government plan. Several factors were not included in this study such as education, politics, income, health, and others. Correlations between all factors 
are needed to find a comprehensive assessment of the social vulnerability index and total risk. Cooperation between the local government and the community association is also needed to implement the mutual assistance strategy.

\section{REFERENCES}

Austroads. (2016). Guide to Traffic Management Part 9: Traffic Operation.

Boyolali District Disaster Management Agency. (2019). Compilation of Mount Merapi Eruption Contingency Plans (in Indonesian). Central Java, Indonesia.

Fatemi, F. (2017). Social vulnerability indicators in disasters: Findings from a systematic review, International Journal of Disaster Risk Reduction, Vol 22, June 2017, page 219227.

Federal Ministry for Economic Cooperation and Development. (2004). Guidelines: Risk Analysis-a Basis for Disaster Risk Management. GTZ GmbH. Eschborn. (https://www.preventionweb.net/files/1085_enriskanalysischs16.pdf)

Glade, T. and Bell, R. (2004). Quantitative Risk Analysis for Landslides-Examples from Bildudalur, NW-Iceland. Natural Hazards and Earth System Sciences 4: 117-131. (C) European Geosciences Union.

Guha-Sapir, D., Hoyois, P., Below, R. (2016). Annual Disaster Statistical Review 2015. CRED: Brussels, Belgium.

Jumadi, Carver, S.J., and Quincey, D.J. (2019). An Agent-Based Evaluation of Varying Evacuation Scenarios in Meapi: Simulatneous and Staged. Geoscience, 9, 317, (www.mpdi.com/journal/geoscience)

Klaten District Disaster Management Agency. (2018). Contingency Plan for Mount Merapi Eruption Disaster (in Indonesian). Central Java, Indonesia.

Klien, J.A., Tucker, C.M., Steger, C.E., Nolin, A., Reid, R., Hopping, K.A., Yeh, E.T., Pradhan, M.S., Taber, A., Molden, D., Ghate, R., Choudhury, D., Alcantara-Ayala, I., Lavorel, S., Gret-Regamey, B.A., Boone, R.B., Bourgeron, P., Castellanos, E., Chen, X., Dong, S., Keiler, M., Seidi, M., Thorn, J., and Yager, K. (2019). An Integrated Community and Ecosystem-Based Approach to Disaster Risk Reduction in Mountain System. Environmental Science and Policy 94(2019)143-152. ELSEVIER. (ecosystemhttps://doi.org/10.1016/j.envsci.2018.12.034).

Lavigne, F., Coster, B.D., Juvin, N., Flohic, F., Gaillard, JC., Texier, P., Morin, J., Sartohadi, J. (2008). People's Behavior in the Face of Volcanic Hazard: Perspective from Javanese Communities, Indonesia. Journal of Volcanology and Geothermal Research 172, 273-287. ScienceDirect, ELSEVIER.

Lowe, C.J. (2010). Analyzing Vulnerability to Volcanic Hazards: Application to St. Vincent. Dissertation. Department of Geography, University Collage, London.

Magelang District Disaster Management Agency. (2017). Merapi Eruption Contingency Plan Document for Magelang Regency 2017-2020 (in Indonesian). Central Java, Indonesia.

Mei, E.T.W., Lavigne, F., Picquout, A., de Bélizal, E., Brunstein, D., Grancher, D., Sartohadi, J., Cholik, N., Vidal, C. (2013). Lessons learned from the 2010 evacuations at Merapi volcano. J. Volcanol. Geotherm. Res. 261, 348-365. 
Nakamura, H., Umeki, H., Kato, T. (2017). Importance of Communication and Knowledge of Disaster in Community-Based Disaster-Prevention Meetings. Safety Science 99 (2017) 235-243. ELSEVIER. (http://dx.doi.org/10.1016/j.ssci.2016.08.024).

Nugraha, A.L., Hani'ah, Firdaus, H.S., Haeriah (2019). Analysisi of Risk Asessment of Mount Merapi Eruption in Settlement Area of Sleman Regency. IOP Conf. Series: Earth and Environmental Science 313, 012003. IOP Publishing. (doi:10.1088/17551315/313/1/012003).

Rahman, K., Ghani, N.A., Kamil, A.A., Mustafa, A. (2012). Analysis of Pedestrian Free Flow Walking Speed in a Least Developing Country: A Factorial Design Study. Research Journal of Applied Sciences, Engineering and Technology 4 (21), 4299-4304. Maxwell Scientific Organization.

Rizvi, S.R., Olariu, S., Weigle, M.C., Rizvi, M.E. (2007). A Novel Approach to Reduce Traffic Chaos in Emergency and Evacuation Scenarios. In Proceedings of the VTC Fall, Baltimore, MD, USA, 30 September-3 October 2007; pp. 1937-1941.

Sangeeth, K., and Lokre, A. (2019). Factors Influencing Pedestrian Speed in Level of Services (LOS) of Pedestrian Facilities. Transportation Research Interdisciplinary Perspectives. ScienceDirect, ELSEVIER Ltd, 3, p. 100066. (doi: 10.1016/j.trip.2019. 100066)

Scarpa, R. Tilling, R.I (1996). Monitoring and Mitigation of Volcano Hazards: Volcanic Hazard Risk Assessment). Pages 675 - 698. Springer-Verlag Berlin Heidelberg. (https://link.springer.com/chapter/10.1007/978-3-642-80087-0_20).

Sleman District Disaster Management Agency. (2019). Merapi Volcano Eruption Contingency Plan (in Indonesian). Yogyakarta, Indonesia.

Transportation Research Board (2000). Highway Capacity Manual: Chapter 18” Pedestrian Methodology. Page 18-4. National Research Council.

Truong, L.T., Kutadinata, R., Espada, I., Robinson, T., Burdan, J., Costa, F., Lin, E. (2018). Walikng Speeds for Timing of Pedestrian Walk and Clearance Intervals. Australasian Transport Research Forum 2018 Proceedings. 30 Oktober- 1 November, Darwin, Australia. (http://www.atrf.info)

Velasquez, G.T (2003). Quantifying the Social Aspects of Disaster Vulnerability. International Training Program on Total Disaster Risk Management. Global Environment Information Center. United Nations University, Japan.

Yosritzal, Kemal, B.M, Purnawan, and Putra, H. (2018). An Observation of the Walking Speed of Evacuee during the a Simulated Stunami Evacuation in Padang, Indonesia. IOP Conf. Series: Earth and Environmental Science 140 (2018) 012090. IOP Publishing.

Zou, B., Lu, C., Mao, S., Li, Y. (2020). Effect of Pedestrian Judgement on Evacuation Efficiency Considering Hesitation. Physica A: Statistical Mechanics and its Applications, 547-122943, ScienceDirect, ELSEVIER. (https://www.sciencedirect.com/science/article /pii/S037843711931667X) 